\title{
Fish prey of the sympatric Galápagos fur seals and sea lions: seasonal variation and niche separation
}

\author{
Thomas Dellinger and Fritz Trillmich
}

\begin{abstract}
Analysis of fish otoliths in scats and vomits of Galápagos fur seals (Arctocephalus galapagoensis) and Galápagos sea lions (Zalophus californianus wollebaeki) was used to determine the numerical composition of the diets for the post-El Niño year 1983, the cold seasons in 1984 and 1985, and the warm season in 1986. Between 84 and $99 \%$ of all otoliths in fur seal scats were from myctophids and bathylagids. The fur seals' diet included 26 species. Only 3 species contributed more than $1 \%$ of otoliths. No seasonal differences in diet were found. Sea lion samples contained a mean of 14 otoliths. Sardines (Sardinops sagax) contributed 75-85\% of otoliths. Sea lions preyed on 24 species, but only 3 surpassed 1\% abundance. Seasonality was not reflected in the sea lions' diet. After the 1982-1983 El Niño, the diets of both species deviated from those in all other years of the study. Food-niche overlap between the two sympatric species was almost non-existent. This is hard to understand, based on our knowledge of the diving capabilities of the two species, but reflects the fact that Galápagos fur seals are nighttime foragers and sea lions are daytime foragers.
\end{abstract}

\begin{abstract}
Résumé : La composition numérique des poissons dans le régime alimentaire a été déterminée par analyse des otolithes contenus dans les fèces et les régurgitations des Otaries de Galápagos (Arctocephalus galapagoensis) et des Lions de mer de Galápagos (Zalophus californianus wollebacki) au cours de l'année post-El Niño, 1983, au cours des saisons froides 1984 et 1985, et au cours de la saison chaude 1986. De 84 à $99 \%$ de tous les otolithes contenus dans les fèces des otaries étaient des otolithes de myctophidés et les bathylagidés. Le régime alimentaire des otaries contenait 26 espèces dont seulement trois ont fourni plus de $1 \%$ des otolithes. Le régime ne subissait pas de variations saisonnières. Les échantillons provenant des lions de mer contenaient en moyenne 14 otolithes. De 75 à $85 \%$ des otolithes étaient des otolithes de Sardines (Sardinops sagax). Les lions de mer se sont nourris de 24 espèces, mais seulement trois d'entre elles ont fourni plus de $1 \%$ des otolithes. Il n'y avait pas de variation saisonnière dans le régime alimentaire des lions de mer. Après El Niño, en 1982-83, le régime alimentaire s'est avéré différent de ce qu'il a été au cours de toutes les autres années. Les régimes alimentaires des deux espèces ne se chevauchaient presque pas, ce qui est étonnant si l'on tient compte de leur capacité de plongée, mais qui s'explique si l'on tient compte des habitudes alimentaires nocturnes des otaries et des habitudes alimentaires diurnes des lions de mer.
\end{abstract}

[Traduit par la Rédaction]

\section{Introduction}

Much is known about the foraging behavior and diet of otariid pinnipeds, the fur seals and sea lions, in areas where just one species occurs (Antonelis et al. 1984; Croxall et al. 1985; Green et al. 1991; Gales and Pemberton 1994; Harcourt et al. 1994). However, the extent or importance of competition between species that are similar in their diving and swimming abilities (Ponganis et al. 1990) has rarely been explored (Antonelis et al. 1990; Green et al. 1990). No long-term information is available on the division of foodresource space between sympatric fur seals and sea lions.

Received June 30, 1998. Accepted May 19, 1999.

Thomas Dellinger. ${ }^{1}$ Marine Biology and Oceanography Section and Center for Biological and Geological Sciences, University of Madeira, P-9000 Funchal, Portugal.

Fritz Trillmich. Department of Animal Behavior, University of Bielefeld, P.O. Box 1001 31, D-33501 Bielefeld, Germany.

${ }^{1}$ Author to whom all correspondence should be addressed (e-mail: dellinger@uma.pt).
Galápagos otariids offer an excellent opportunity to study dietary-niche overlap within a relatively small, confined area where a fur seal and a sea lion occur in close sympatry.

Moreover, little is known about the food of tropical otariids, which live in much less productive waters than the larger subpolar and temperate-zone pinniped populations. It therefore appears important to learn more about the kinds of food taken by tropical otariids, as well as the strategies they use to deal with a variable, low-productivity environment (Gentry et al. 1986; Trillmich and Ono 1991). Information published so far is very limited and concerns mostly squid prey of Galápagos fur seals (Clarke and Trillmich 1980), as well as providing limited documentation of the changes in food choice of Galápagos fur seals and sea lions immediately after the 1982-1983 El Niño (Trillmich and Dellinger 1991).

Pinnipeds living in the Galápagos archipelago depend entirely on a local upwelling zone that provides rich food resources amidst a tropical ocean low in productivity. A minor reduction in upwelling happens regularly on a seasonal basis. Every year, the period from December to May is warmer and calmer than the cold season from June to November. 
However, more serious declines in marine productivity occur quite frequently (about every 3-7 years) during El Niño Southern Oscillation (ENSO) events (Glynn 1988; Trillmich and Ono 1991). These events lead to a decline in the local circulation, a reduction in upwelling, and an increase in seasurface temperature (SST) and are accompanied by greatly reduced primary and secondary productivity (Arntz and Trillmich 1991). Food resources are thus geographically narrowly circumscribed and seem rather limited for the lowdensity populations of Galápagos fur seals (Arctocephalus galapagoensis) and Galápagos sea lions (Zalophus californianus wollebaeki). These populations are small, comprising only 20000 - 30000 animals (Trillmich 1987). Galápagos pinnipeds last suffered a dramatic decline during the 1982-1983 El Niño (Trillmich and Limberger 1985; Trillmich and Dellinger 1991), when fur seal numbers decreased by about $50-70 \%$ and sea lion numbers by approximately $30 \%$ (Trillmich and Dellinger 1991). The variability in primary productivity leads to a highly variable food supply, which strongly influences adult and juvenile survival as well as growth of young to independence (Trillmich 1990; Horning and Trillmich 1997).

Based on a 4-year study we here $(i)$ analyze the fish diets of Galápagos fur seals and sea lions from fecal analysis, (ii) analyze dietary variability among years as well as seasons, and (iii) investigate the extent of competition between sympatric Galápagos fur seals and sea lions for the same food resources.

\section{Material and methods}

The study was conducted at Cabo Hammond $\left(0^{\circ} 28^{\prime} \mathrm{S}, 91^{\circ} 37^{\prime} \mathrm{W}\right)$ in the southwestern corner of Fernandina Island, which is the westernmost of the Galápagos Islands. Samples were collected during the cold season in 1983-1985 (September-October) and the warm season in 1986 (March-April). The sampling periods are given in Table 1 and the numbers of samples and otoliths found are listed in Table 2. Most of the samples stem from mothers with juveniles, as we were collecting in places frequented by these animals.

Scats were collected at sites that were exclusively used by either fur seals or sea lions. Furthermore, scats of the two species are easily distinguished by their size, consistency, and color. In every season we collected scats about eight times per species. Collection days were spaced so as to cover an entire lunar cycle, with slightly more frequent sampling around full moon, when the number of fur seals ashore peaks (Trillmich and Mohren 1981). Only fresh scats (still moist and dark in color) were collected. Older scats looked sun-bleached and dry.

In 1983 we also collected vomits of both species. In that year, 49 out of 106 sea lion samples and 7 out of 138 fur seal samples were vomits. All other samples in that and all other years were scats. In one fresh sea lion vomit we found 14 undigested sardines (Sardinops sagax). Their standard length and otolith length were measured and used for regression analysis. For estimating mass from otolith length for sardines we used this regression and the one by Villavicencio de Muck and Muck (1983) relating standard length (StL) to body mass $(W): W=0.015 \times \mathrm{StL}^{3}$.

Scats and vomits were immersed in soapy water for about $48 \mathrm{~h}$, stirred repeatedly during this time, and then screened through a series of three sieves with mesh widths of $2.0,1.0$, and $0.5 \mathrm{~mm}^{2}$ stacked on top of one another. In 1983 we used only the 2.0 and $1.0 \mathrm{~mm}^{2}$ mesh sieves. Tweezers were used to collect otoliths and cephalopod beaks from the sieves and transfer them to small plastic vials. Items were then washed twice with $70 \%$ alcohol, dried, and stored dry. In 1983, 13 sea lion samples and 32 fur seal samples were also passed through a household sieve with fine mesh (approximately $0.55-0.6 \mathrm{~mm}^{2}$ ). However, since this finer screening yielded only 6 additional otoliths out of 128 otoliths $(4.7 \%)$, we abandoned it and we consider the probability of finding otoliths with this technique to be nearly identical with that in other years of study.

Sagittal otoliths were sorted using a Wild stereomicroscope at 10-30× magnification. Otolith types (OT) were numbered sequentially as they were encountered. Well-preserved specimens were photographed and used for reference when typing specimens encountered later. Unidentifiable, greatly damaged otoliths or otolith parts were excluded, amounting over all years to 68 pieces $(1.36 \%$ of all items) for sea lions and 5 pieces $(0.03 \%)$ for fur seals. OT frequencies were determined separately for every scat sample. Species identification was facilitated by using the reference collections of W. Arntz (collected in Peru; deposited in the Alfred Wegener Institute for Polar and Marine Research, Bremerhaven, Germany), J. Fitch (Los Angeles County Museum, U.S.A.; species were kindly identified for us by J. Groves, R.J. Lavenberg, and G.A. Antonelis), and the Southwest Fisheries Center (San Diego, Calif., U.S.A.; species were identified by Mark Lowry and S. Hawes). Otolith 8 was identified by T. Hecht. Unidentified otoliths are referred to by their OT number. Cephalopod beaks were found exclusively in fur seal scats, where they amounted (over all years) to $3.8 \%$ of all items found. They have not yet been identified and are not included in the analysis.

Otoliths in samples with a large number of well-preserved otoliths were measured to the nearest $0.1 \mathrm{~mm}$ at about $30 \times$ magnification to determine size distributions. Only intact otoliths showing surface structure, a deep sulcus, clearly structured margins, and an excisura ostii with few signs of digestion were used for measuring length (see Hecht 1978).

Inferring diet from otoliths in fecal samples is difficult (Beddington et al. 1985). We based our analysis on the following three assumptions. (1) We assumed that ratios of different prey items in scats were unbiased. Digestion has different effects on otoliths of different prey species and, within a species, individuals of different sizes (da Silva and Neilson 1985; Murie and Lavigne 1985; Härkönen 1986; Jobling and Breiby 1986; Dellinger and Trillmich 1988; Pierce et al. 1993). This leads to bias in estimating diet composition. However, Dellinger and Trillmich (1988) tested differential digestion in the California sea lion (Zalophus californianus californianus) and the South American fur seal (Arctocephalus australis), which are closely related to our studied species, and concluded that in a large sample of scats, prey ratios were not seriously biased. Since we never collected fewer than 45 samples per species in a given season, we consider our samples large enough to prevent major bias. Partial digestion of otoliths will nevertheless reduce the estimated size of prey items. This problem was minimized, however, since we selected the best-preserved sardine otoliths to derive an estimate of sea lion prey size. No such estimate was derived for fur seal prey because of the lack of regression curves of otolith length on fish size for myctophids and bathylagids. (2) Prey proportions in samples found on land, in the Galápagos area, were assumed to reflect closely the proportion taken at sea. Feces found ashore may represent only part of the diet spectrum because otoliths of fishes eaten early in the trip could have been voided by the time an animal returned to shore. The duration of foraging trips was $8 \pm 1.6 \mathrm{~h}$ (mean $\pm \mathrm{SD}$ ) for 32 female Galápagos fur seals (Horning and Trillmich 1997), including a return transit time of $2 \pm 1 \mathrm{~h}$ (Kooyman and Trillmich 1986a). For sea lions, corresponding estimates are $16 \pm 1 \mathrm{~h}(n=14)$ and $2 \pm$ $1 \mathrm{~h}$ (Kooyman and Trillmich 1986b). Given that the bulk of otoliths are passed only after about $20 \mathrm{~h}$ (Dellinger and Trillmich 1988), scats of both species should still reflect most meals. Moreover, pinnipeds are unlikely to encounter different prey species on the inward trip, since around Fernandina Island the bottom reaches depths $>1000 \mathrm{~m}$ within 4-5 km offshore. (3) Sea lion scats had a 
Table 1. Sea-surface temperatures (SST; measured at noon) during the study periods at Cabo Hammond, Fernandina Island.

\begin{tabular}{lll}
\hline & \multicolumn{2}{l}{ SST $\left({ }^{\circ} \mathrm{C}\right)$} \\
\cline { 2 - 3 } & Mean \pm SD & Range \\
\hline 1 Sept. -24 Oct. 1983 & $18.5 \pm 1.2$ & $16.0-21.6$ \\
26 Aug. -5 Nov. 1984 & $18.5 \pm 2.3$ & $15.1-22.7$ \\
2 Oct. -19 Nov. 1985 & $18.1 \pm 1.6$ & $14.9-21.2$ \\
10 Mar. -23 Apr. 1986 & $21.2 \pm 2.6$ & $17.9-27.0$ \\
\hline
\end{tabular}

Note: The periods in 1983, 1984, and 1985 were during the cold season; the period in 1986 was during the warm season.

much larger volume than fur seal scats but contained only a mean of 15 otoliths, whereas those of fur seals contained 50. Sea lions might be eating larger prey. Under the experimental conditions of Dellinger and Trillmich (1988), about 35\% of all otoliths were totally digested, but there was no indication that sea lions digested more otoliths than fur seals. Therefore, the assumption that sea lions fed on larger prey seems warranted. Even if they were digesting more otoliths than fur seals, this would not affect our conclusions as long as the assumption of unbiased prey ratios holds.

To compare samples we used the number of otoliths (frequency), the number of samples (= scats) in which a given OT occurred (occurrence), and the number of samples in which a given OT was dominant, i.e., most abundant (dominance). Percentages were calculated by relating these values to yearly or overall totals of otoliths or to the total number of scats (percent frequency, percent occurrence, percent dominance). Furthermore, we used the following indices (from Magurran 1988): the inverse Berger-Parker index, $N / N_{\max }$, where $N$ is the total number of otoliths in a sample and $N_{\max }$ is the number of the most frequent occurring OT in the sample, Shannon's index of diversity, $H$, where $p_{i}$ is the proportion of the $i$ th OT in the sample,

$$
H=-\sum_{i=1}^{n} p_{i} \ln p_{i}
$$

and Colwell and Futuyma's (1971) index of niche overlap $(C)$ :

$$
C=1-1 / 2 \times \sum_{j=1}^{n} p_{1 j}-p_{2 j}
$$

where $p_{1 j}$ and $p_{2 j}$ are the probabilities of occurrence of the $j$ th OT for the two species, sea lion and fur seal.

During every field season, SST was measured daily at noon using an electronic thermometer accurate to $0.1^{\circ} \mathrm{C}$ (Testoterm, Lenzkirch, Germany).

Statistical analyses were performed using the SPSS package (SPSS Inc. 1997) following standard textbooks (e.g., Zar 1984). All significance values reported are two-tailed. Details of tests used are given in the text.

\section{Results}

\section{Marine conditions}

The study was conducted during the cold season in 19831985. In the western islands, the cold season is characterized by strong upwelling and high marine productivity. Mean SST remained around $18-19^{\circ} \mathrm{C}$ and did not vary significantly among years (Table 1). In 1983, however, the strongest El Niño of the century had just ended in July and marine conditions had not yet returned to normal (Fahrbach et al. 1991). In 1986, the study took place during part of the local warm season, which was characterized by increased
SSTs caused by reduced upwelling. The mean SST was almost $3^{\circ} \mathrm{C}$ higher than in the previous years of study (Table 1) and differed significantly from that in all other years (ANOVA, Tukey's post hoc difference among means, $p<$ $0.01)$.

\section{Fur seal diet}

\section{Diet composition}

In 300 (= 295 non-empty) fur seal samples we found 15036 otoliths. Seven vomits collected in 1983 were included in the analysis, since their composition (measured as the number of samples in which a given OT was dominant) did not differ from that of the 131 scat samples collected in $1983\left(\chi^{2}=3.9\right.$, df $\left.=2, p>0.1\right)$. Samples contained an average of 50 otoliths (Table 2). We identified 26 OTs, 13 of them to species or family level. Table 2 gives the overall frequencies of all important OTs by year.

During all 4 years of the study most otoliths belonged to fishes of the families Myctophidae and Bathylagidae, the as yet unidentified myctophid OT 10 being the most abundant single species, contributing 10577 otoliths, followed by bathylagid OT 16 with 2862 otoliths (Fig. 1, Tables 2 and 3). Myctophids and bathylagids together, representing 6 different OTs, varied in percent frequency among years from 85 to $99 \%$ (Table 2). Two other families, Clupeidae and Carangidae, represented by the sardine (OT 1) and Selene declivifrons (OT 29), respectively, and a third, unidentified OT, 31, surpassed 1\% only in 1983; all other OTs remained below this frequency in every year (Table 2).

Whenever the most frequent OT decreased in the diet, one of the more rarely eaten OTs increased (Table 2, Fig. 1). The distribution of prey species frequency for all years combined was indistinguishable from a logarithmic series $\left(\chi^{2}=13.0\right.$, df $=4, p=0.4$; Magurran 1988).

\section{Differences among seasons and years}

There was no clear seasonal difference between the warm season in 1986 and all three cold-season years despite great variability in diet choice among years (see Tables 2, 3, and 5). In 1983, fur seals preyed on a total of 18 different fish species (OTs), while in other years the number ranged from 12 to 14 (Table 2). The average number of OTs per scat was highest in 1984, second highest in 1985, and lowest in 1986 (Table 2). Scats contained $2.74 \pm 1.5$ OTs. The number of species found per scat varied significantly among years (ANOVA, $\mathrm{df}=3, p<0.001$ ). In 1986, fur seals had the fewest species per scat $(2.06 \pm 1.1 \mathrm{OTs} / \mathrm{scat})$. This low value differed significantly from those in all other years (post hoc Tukey's test, $p<0.05)$. The diet was most diverse in 1984 $(3.32 \pm 1.7$ OTs/scat $)$.

The number of otoliths per scat was lowest in 1983, post El Niño, and during the warm season in 1986. It was about twice as high during the cold season in 1984 and 1985 (Table 2). When occurrence was used as an index of diet composition, all years differed significantly from each other (Table $3 ; \chi^{2}=145$, df $=21,7$ OTs over 4 years; $p<0.001$; only OTs that that were more frequent than $2 \%$ in any year are included). As shown in Fig. 2, percent occurrence of each OT varied less among years than percent frequency.

The most conspicuous change in prey items among years was the unusually high frequency of the bathylagid OT 16 
Table 2. Percent numerical frequency of otoliths in scat and vomit samples from Galápagos sea lions and fur seals.

\begin{tabular}{|c|c|c|c|c|c|c|c|c|c|c|c|}
\hline \multicolumn{2}{|c|}{ Otolith type (OT) } & \multicolumn{5}{|c|}{ Fur seals } & \multicolumn{5}{|c|}{ Sea lions } \\
\hline No. & Species or family & 1983 & 1984 & 1985 & 1986 & All years & 1983 & 1984 & 1985 & 1986 & All years \\
\hline \multicolumn{12}{|c|}{ Percent frequency } \\
\hline 2 & Trachurus symmetricus & 0.26 & & & 0.04 & 0.09 & 0.64 & & 0.97 & 2.05 & 1.16 \\
\hline 4 & Scomber japonicus & 0.02 & & 0.04 & & 0.02 & 1.28 & 0.46 & 0.55 & 0.72 & 0.76 \\
\hline 6 & Pontinus furcirhinus & & & & & & 0.64 & & & 0.83 & 0.44 \\
\hline 10 & Myctophidae & 75.30 & 38.47 & 76.94 & 87.03 & 70.34 & 0.09 & 0.76 & 0.28 & 0.44 & 0.36 \\
\hline 14 & Physiculus talarae & & & & & & 0.18 & & 0.14 & 0.50 & 0.26 \\
\hline 15 & $\begin{array}{l}\text { Lampadaena sp. } \\
\text { (Myctophidae) }\end{array}$ & 4.23 & 1.36 & 0.10 & 0.31 & 1.78 & & & & & \\
\hline 16 & Bathylagidae & 2.56 & 56.54 & 18.63 & 7.85 & 19.03 & & 0.61 & & 0.06 & 0.10 \\
\hline 26 & $\begin{array}{l}\text { Lampadaena sp. } \\
\text { (Myctophidae)? }\end{array}$ & 0.12 & 1.66 & 0.36 & 0.13 & 0.50 & & 0.15 & 0.34 & 0.55 & 0.32 \\
\hline 28 & Engraulis ringens & 0.91 & 0.71 & & & 0.45 & & 1.82 & 0.90 & 1.33 & 0.98 \\
\hline 29 & Selene declivifrons & 4.59 & 0.10 & & & 1.57 & & & & & \\
\hline 30 & Cubiceps pauciradiatus & 0.10 & 0.03 & & & 0.04 & & & & & \\
\hline \multicolumn{2}{|c|}{ Other otoliths } & 3.23 & 0.34 & 0.63 & 1.52 & 1.58 & 0.73 & 0.15 & 7.03 & 5.97 & 4.37 \\
\hline \multicolumn{2}{|c|}{ No. of different OTs } & 6 & 4 & 5 & 4 & 13 & 4 & 1 & 4 & 7 & 12 \\
\hline \multicolumn{12}{|c|}{ Totals } \\
\hline \multicolumn{2}{|c|}{ No. of otoliths } & 5077 & 2950 & 4766 & 2243 & 15036 & 1097 & 659 & 1450 & 1808 & 5014 \\
\hline \multicolumn{2}{|c|}{ No. of scats } & 138 & 38 & 58 & 66 & 300 & 106 & 52 & 76 & 108 & 342 \\
\hline \multicolumn{2}{|c|}{ No. of otoliths/scat } & 37 & 78 & 82 & 34 & 50 & 10 & 13 & 19 & 17 & 15 \\
\hline
\end{tabular}

Note: Otoliths of unidentified species are grouped, and the number of OTs of which they consisted is given. Damaged otoliths are not included.

and the equally unusually low frequency of myctophid OT 10 in 1984 (Table 2, Fig. 2). Although the frequencies of OT 10 and OT 16 differed strongly between 1984 and 1985 (Table 2), their percent occurrence did not (Fig. 2). When percent frequency of OT 10 in the diet almost halved from 1983 to 1984 , its percent occurrence stayed nearly the same (Fig. 2). In 1984, fur seals fed mainly on OT 16, which occurred in $97 \%$ of scats and composed $56.54 \%$ of all otoliths (percent frequency). In 1985 they still took this prey frequently (i.e., 95\% occurrence), but it only amounted to $18.63 \%$ frequency of otoliths for those years (Table 2 and Fig. 2). Analysis of differences among years based on the dominance of just these two OTs also showed that 1983 and 1986 differed from 1984 and $1985\left(\chi^{2}\right.$ always $>6$, df $=1, p<$ $0.05)$, but not 1984 from $1985(p=0.8)$ nor the 1983 postEl Niño season from the warm season in $1986(p=0.4)$. The unusual diet composition in 1984 was also obvious in the among-years intraspecific niche-overlap index (Table 5). The index separated 1984 from all other years. Apparently, food choices of fur seals in the post-El Niño year 1984 differed widely from those in other years.

\section{Otolith sizes}

Variance in otolith size among years was always significant (Kruskal-Wallis test, $p<0.001$ ), pointing to changes in age structure or availability of different age-classes of prey over the years. Sardines contributed a major part of the fur seals' diet only in 1983, and individual prey items were of the same size as those taken by sea lions in 1983 (Table 6). Too few undamaged sardine otoliths were found in fur seal scats in the later years to allow meaningful comparison. Myctophid OT 10 was relatively large in 1983, decreased in size in 1984 and 1985, and returned to its previous size in 1986 (Table 6). Between 1983 and 1985, bathylagid OT 16 varied in size only slightly and was smallest in 1986 during the warm season (Table 6). Owing to the lack of a standard curve, the sizes of individual myctophid and bathylagid prey taken cannot be estimated at present.

\section{Sea lion diet}

\section{Prey species composition}

In 342 sea lion scats and vomits we found 5014 otoliths. Scats contained, on average, 15 otoliths, a much smaller number than was found in fur seal scats (Table 2). Overall, sea lions fed on 24 different fish species, of which 12 were identified (to at least family level; Tables 2 and 4). Vomits, found only in 1983, and scats found in the same year did not differ significantly in occurrence of each OT $\left(\chi^{2}=6.1\right.$, df $=$ $5, p=0.3)$, but did differ in respect to dominance $\left(\chi^{2}=11.0\right.$, $\mathrm{df}=1, p<0.001)$. Since vomits were obtained only in 1983 , 
Table 3. Frequency, occurrence, and dominance of otolith types (OTs) observed for fur seals during each year of the study.

\begin{tabular}{|c|c|c|c|c|c|}
\hline & 1983 & 1984 & 1985 & 1986 & Total \\
\hline \multicolumn{6}{|c|}{$\begin{array}{l}\text { Sardinops sagax (sardine) } \\
\text { (OT 1) }\end{array}$} \\
\hline Frequency & 302 & 13 & 10 & 17 & 342 \\
\hline Occurrence & 77 & 6 & 5 & 5 & 93 \\
\hline Dominance & 32 & 1 & 0 & 1 & 34 \\
\hline \multicolumn{6}{|c|}{ Myctophidae (OT 10) } \\
\hline Frequency & 3823 & 1135 & 3667 & 1952 & 10577 \\
\hline Occurrence & 107 & 35 & 56 & 62 & 266 \\
\hline Dominance & 80 & 8 & 40 & 58 & 186 \\
\hline \multicolumn{6}{|c|}{$\begin{array}{l}\text { Lampadaena sp. } \\
\text { (Myctophidae) (OT 15) }\end{array}$} \\
\hline Frequency & 214 & 40 & 5 & 7 & 267 \\
\hline Occurrence & 30 & 7 & 2 & 1 & 40 \\
\hline Dominance & 1 & 0 & 0 & 0 & 1 \\
\hline \multicolumn{6}{|c|}{ Bathylagidae (OT 16) } \\
\hline Frequency & 130 & 1668 & 888 & 176 & 2862 \\
\hline Occurrence & 39 & 37 & 54 & 29 & 159 \\
\hline Dominance & 0 & 24 & 15 & 4 & 43 \\
\hline \multicolumn{6}{|c|}{$\begin{array}{l}\text { Leuroglossus sp. } \\
\quad \text { (Bathylagidae) (OT 18) }\end{array}$} \\
\hline Frequency & 103 & 10 & 140 & 18 & 271 \\
\hline Occurrence & 34 & 7 & 25 & 8 & 74 \\
\hline Dominance & 0 & 0 & 1 & 0 & 1 \\
\hline \multicolumn{6}{|c|}{$\begin{array}{l}\text { Selene declivifrons } \\
\text { (OT 29) }\end{array}$} \\
\hline Frequency & 233 & 3 & & & 236 \\
\hline Occurrence & 19 & 1 & & & 20 \\
\hline Dominance & 9 & 0 & & & 9 \\
\hline \multicolumn{6}{|l|}{ OT 31} \\
\hline Frequency & 144 & 1 & & & 145 \\
\hline Occurrence & 7 & 1 & & & 8 \\
\hline Dominance & 1 & 0 & & & 1 \\
\hline \multicolumn{6}{|l|}{ Other OTs } \\
\hline Frequency & 127 & 80 & 56 & 73 & 336 \\
\hline Occurrence & 66 & 32 & 29 & 27 & 154 \\
\hline Dominance & 4 & 0 & 0 & 0 & 4 \\
\hline \multicolumn{6}{|l|}{ Total } \\
\hline Frequency & 5077 & 2950 & 4766 & 2243 & 15036 \\
\hline Occurrence & 136 & 38 & 57 & 64 & 295 \\
\hline Dominance & 127 & 33 & 56 & 63 & 279 \\
\hline
\end{tabular}

Note: Only samples containing otoliths were considered in the calculations. OTs that remained below $2 \%$ of the total number of otoliths in any year were pooled. Numerical equality between dominant OTs in a particular sample precluded its inclusion in the dominance count.

scats and vomits were analyzed without regard to this distinction.

In all 4 years of the study, sardines (OT 1) were the most important food item in the diet of sea lions, varying among years from 75 to $85 \%$ frequency and occurring in virtually all samples (93-98\% occurrence; Table 4, Fig. 2). Together with the second most important species Chlorophthalmus sp. (OT 8; presumably C. agassizii, T. Hecht, personal communication) they amounted to $87-96 \%$ frequency in all years (Table 2). Only 3 further OTs surpassed $1 \%$ overall frequency (Tables 2 and 4, Fig. 2). A reduced frequency of sardines in samples was accompanied by increased frequencies of other OTs (Table 2, Fig. 3). The distribution of prey species frequencies for all years combined was indistinguish- able from a logarithmic series $\left(\chi^{2}=4.05\right.$, df $=7, p<0.78$; Magurran 1988).

Differences among seasons and years

The sea lion diet did not differ clearly in composition between the warm season in 1986 and all three cold seasons. Sardines were always the main food item (Table 2). Sardine otoliths varied in percent frequency among years, but much less so in percent occurrence (Fig. 2). Year-to-year changes in occurrence of the two most dominant species (sardine and Chlorophthalmus sp.) were differentiated from each other only in 1984 and $1985\left(\chi^{2}=4.3\right.$, df $\left.=1, p<0.04\right)$. Because sardine otoliths were so dominant in all years, intraspecific niche-overlap indices between years were rather similar (Ta- 
Fig. 1. Changes in percent dominance of prey in the fur seal diet (the most frequent otolith type (OT) in scats, expressed as a percentage, scats for each sampling period) over the 4 years of the study. Note that the changes in dominance of OT 10 (Myctophidae) are the opposite of the changes in dominance of the other OTs.

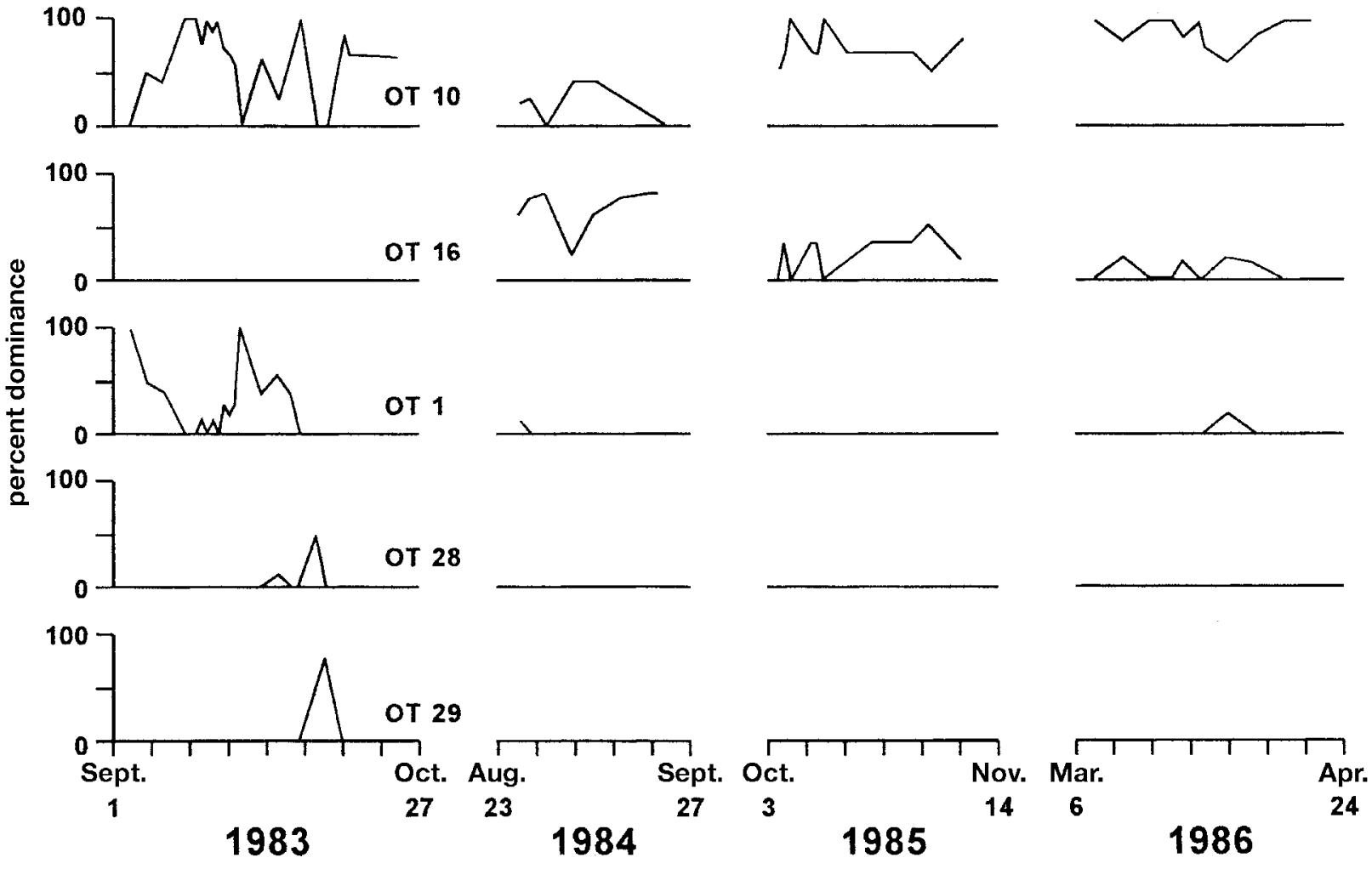

ble 5). The most obvious change in species composition was the high frequency of Chlorophthalmus sp. otoliths in 1984, occurring simultaneously with a marked decrease in sardine otoliths. This inverse relation was also observed in 1983 (Tables 2 and 4, Fig. 3). In a one-way ANOVA, year significantly influenced species number (OTs/scat; $F_{[3]}=4.56, p=$ $0.004)$. The number of species in the diet was highest in the warm season in $1986(1.90 \pm 1.18 \mathrm{OTs} / \mathrm{scat})$. This effect separated 1986 only from 1983 (lowest number of species per sample, $1.45 \pm 0.75$ OTs/scat) and not from the remaining years (post hoc Tukey's test between 1983 and 1986, $p$ < 0.05). Year did not influence the dominance index (BergerParker index/scat, $\left.F_{[3]}=1.46, p=0.23\right)$ or Shannon's diversity index ( $H$ value/scat, $\left.F_{[3]}=2.14, p=0.096\right)$.

\section{Otolith lengths}

Otolith lengths differed significantly between years (Table 6; Kruskal-Wallis test for OT 1 and OT $8, p<0.001$ ). OT 1 tended to be largest in 1983, smaller in 1984, and increase in size in 1985 and 1986 (Table 6). Otoliths of Chlorophthalmus sp. also varied considerably in size among years (Table 6). From the 14 intact sardines found in sea lion vomits in 1983 we calculated the regression of StL on otolith length $(\mathrm{OL})(\mathrm{StL}=3.079 \times \mathrm{OL}+4.009)$. From the mean sardine otolith length in our samples, total length was estimated at $13.4 \mathrm{~cm}$ and mass at $36.2 \mathrm{~g}$ for sardines (Villavicencio de Muck and Muck 1983). Considering that mass estimates are generally too low (Dellinger and Trillmich 1988), this corresponds to a corrected estimated mass of about $56 \mathrm{~g}$. A similar estimate for Chlorophthalmus sp. is impossible, owing to the lack of a standard curve.

\section{Comparison of fur seals and sea lions}

The sea lion diet was less diverse $(H=0.24 \pm 0.35)$ than the fur seal diet $(H=0.46 \pm 0.35)$. This is reflected in the number of OTs per sample, which, averaged over all years, was only $1.68 \pm 0.97$ for sea lions but $2.74 \pm 1.51$ for fur seals (Fig. 4).

In all years of the study, fur seals and sea lions foraged for widely different prey. Only in 1983, in the aftermath of the 1982-1983 El Niño, did fur seals take appreciable amounts of sardines, but sea lions never took more than $1 \%$ of bathylagids and myctophids (Fig. 4, Table 2). These almost completely different food spectra for the two species were reflected in the low values of the niche-overlap index (Table 5).

\section{Discussion}

\section{Diet choice}

\section{Fur seals}

Myctophid and to a lesser extent bathylagid fish are part of the deep scattering layer, which migrates to the surface during the night. This explains why Galápagos fur seals are exclusively nocturnal foragers (Kooyman and Trillmich 1986a; Horning and Trillmich 1997). This species appears to specialize on the deep scattering layer. 
Fig. 2. Percent frequency and percent occurrence of OTs in sea lion and fur seal samples over the 4 years of the study. Note the almost independent variation of the two measures.

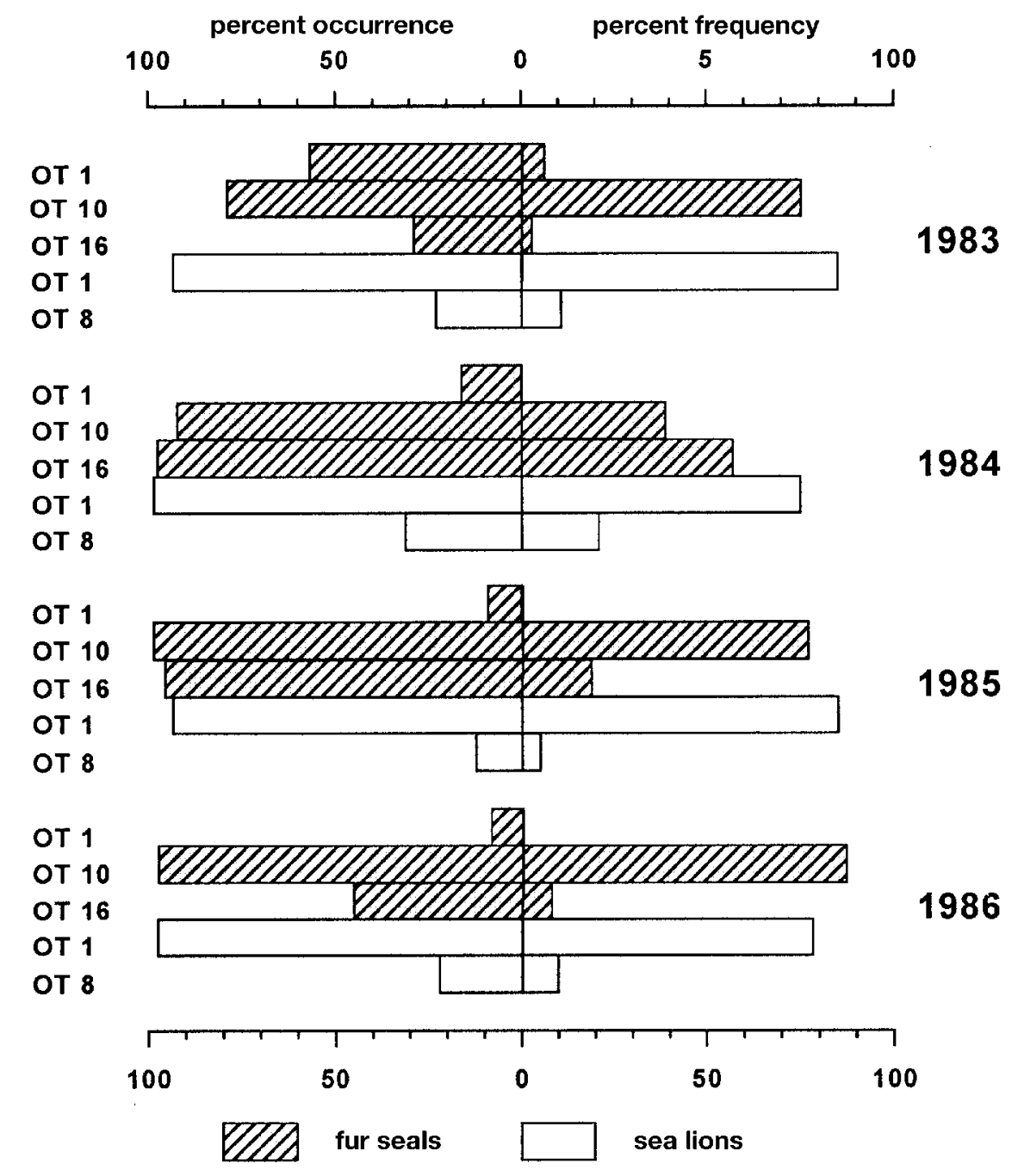

All fur seal species investigated to date (with the exception of large female northern fur seals) are mainly nocturnal feeders (Gentry et al. 1986; Gentry 1998), taking vertically migrating shoaling fish (clupeids and gadids) and cephalopods. An exception is the Antarctic fur seal, Arctocephalus gazella, which feeds largely on krill (North et al. 1983; Doidge and Croxall 1985; Reid 1995; Reid and Arnould 1996). A limited data set on the South American fur seal, Arctocephalus australis, indicates that it usually feeds on dense, shoaling prey, mainly clupeids and carangids (VazFerreira 1982; Vaz-Ferreira and Ponce de Leon 1987; Majluf 1991). However, under food limitation, these pinnipeds also took myctophids and bathylagids from the deep scattering layer (Majluf 1991). Other otariids feed on myctophids and bathylagids on a more seasonal basis. The Antarctic fur seal takes more of this prey during autumn and winter (Green et al. 1989, 1991; Daneri and Coria 1992, 1993; Reid 1995; Reid and Arnould 1996), and at Macquarie Island, Australia, where three fur seal species (A. gazella, Arctocephalus tropicalis, and Arctocephalus forsteri) coexist, from November to March they fed on the myctophid genera Electrona and Gymnoscopelus (Green et al. 1990). Northern fur seals occasionally take myctophids and bathylagids (Kajimura 1984;
Perez and Bigg 1986), and one species of bathylagid was first described from seal stomachs (Lucas 1899). The only other fur seal species, which seems to specialize on myctophids and cephalopods, is the Juan Fernández fur seal, Arctocephalus philippii (Francis et al. 1998).

Myctophids form an ideal diet for an animal that is adapted for nocturnal visual hunting. They are energy-dense, with a mean value of $7 \mathrm{~kJ} / \mathrm{g}$ wet mass in the king penguin's (Aptenodytes patagonica) diet (Cherel and Ridoux 1992) and $5.2 \mathrm{~kJ} / \mathrm{g}$ in that of the tropical species Lepidophanes guentherii (Gartner 1993). Furthermore, they constitute the dominant group of vertically migrating oceanic fishes and account for the largest share of fish biomass near the surface at night in low-latitude communities (Paxton 1967; Clarke 1973; Maynard et al. 1975; Hopkins and Gartner 1992).

Myctophids are rather small fishes with large otoliths. We do not know the species of our most common myctophid, OT 10, but use of regression equations published for various myctophid species (Gartner 1991; Linkowsky 1991) yielded an average otolith size of $3.6 \mathrm{~mm}$, as found in this study, for fishes between 60 and $140 \mathrm{~mm}$ standard length. The myctophid community near Hawai'i covered a size range of 7-140 mm standard length, with modal sizes around 60- 
Table 4. Frequency, occurrence, and dominance of otolith types (OTs) observed for sea lions during each year of the study.

\begin{tabular}{|c|c|c|c|c|c|}
\hline & 1983 & 1984 & 1985 & 1986 & Total \\
\hline \multicolumn{6}{|c|}{$\begin{array}{l}\text { Sardinops sagax (sardine) } \\
\text { (OT 1) }\end{array}$} \\
\hline Frequency & 936 & 493 & 1229 & 1406 & 4064 \\
\hline Occurrence & 95 & 50 & 71 & 104 & 320 \\
\hline Dominance & 87 & 42 & 70 & 93 & 292 \\
\hline \multicolumn{6}{|c|}{$\begin{array}{l}\text { Trachurus symmetricus } \\
\text { (OT 2) }\end{array}$} \\
\hline Frequency & 7 & & 14 & 37 & 58 \\
\hline Occurrence & 5 & & 4 & 8 & 17 \\
\hline Dominance & 2 & & 1 & 2 & 5 \\
\hline \multicolumn{6}{|c|}{$\begin{array}{l}\text { Chloropthalmus sp. } \\
\text { (agassizii?) (OT 8) }\end{array}$} \\
\hline Frequency & 117 & 140 & 73 & 177 & 507 \\
\hline Occurrence & 23 & 16 & 9 & 23 & 71 \\
\hline Dominance & 9 & 6 & 2 & 4 & 21 \\
\hline \multicolumn{6}{|l|}{ OT 34} \\
\hline Frequency & & & 65 & 15 & 80 \\
\hline Occurrence & & & 28 & 13 & 41 \\
\hline Dominance & & & 0 & 0 & 0 \\
\hline \multicolumn{6}{|l|}{ OT 39} \\
\hline Frequency & & & 33 & 5 & 38 \\
\hline Occurrence & & & 5 & 3 & 8 \\
\hline Dominance & & & 0 & 0 & 0 \\
\hline \multicolumn{6}{|l|}{ OT 43} \\
\hline Frequency & & & 1 & 77 & 78 \\
\hline Occurrence & & & 1 & 6 & 7 \\
\hline Dominance & & & 0 & 2 & 2 \\
\hline \multicolumn{6}{|l|}{ Other OTs } \\
\hline Frequency & 37 & 26 & 35 & 91 & 247 \\
\hline Occurrence & 19 & 10 & 16 & 37 & 82 \\
\hline Dominance & 0 & 0 & 0 & 1 & 1 \\
\hline \multicolumn{6}{|l|}{ Total } \\
\hline Frequency & 1097 & 659 & 1450 & 1808 & 5014 \\
\hline Occurrence & 102 & 51 & 76 & 107 & 336 \\
\hline Dominance & 98 & 48 & 73 & 102 & 321 \\
\hline
\end{tabular}

Note: For details see Table 3.

$70 \mathrm{~mm}$ (Clarke 1973). Assuming that Galápagos myctophids are of similar sizes, Galápagos fur seals fed predominantly on adult fish in the upper size range.

Myctophids commonly aggregate with other organisms (Auster et al. 1992), and many squid are known to feed on them (Kear 1992; Rodhouse et al. 1992) or co-occur with them. This would explain the occurrence of squid in the diet of fur seals (Clarke and Trillmich 1980). Bathylagids also undertake diel migrations (Cailliet and Ebeling 1990). They seem to have a more seasonal occurrence pattern than myctophids (Cailliet and Ebeling 1990; Miya 1994), and were abundant in Galápagos fur seal scats only in 1984.

\section{Sea lions}

Galápagos sea lions are largely daytime feeders (Kooyman and Trillmich 1986b). In contrast to fur seals, they fed mainly on pelagic shoaling fish, which show only minor vertical migrations, such as sardines and jack mackerel (Trachurus symmetricus), or demersal shoaling fish like Chlorophthalmus sp. These prey species are also energy- dense, with values above $7 \mathrm{~kJ} / \mathrm{g}$ wet mass (Bowen and Harrison 1996). California sea lions off the west coast of North America also feed on schooling fish foraging during the day and at night (Hobson 1966; Huber et al. 1979; Bailey and Ainley 1982; Aurioles et al. 1984; Feldkamp et al. 1989). From Washington State to Point Conception, California, Pacific hake (Merluccius productus) is the single most frequent prey (Everitt et al. 1981; Ainley et al. 1982; Bailey and Ainley 1982), followed by other items depending on geographical location, the most important being market squid (Loligo opalescens), rockfish (Sebastes sp.), and northern anchovy (Engraulis mordax) (Ainley et al. 1982). Apart from anchovy, this diet composition contrasts with our findings in that squid, which occur in the Galápagos Islands and are regularly taken by fur seals, were never found in sea lion scats or vomits. Gadids such as hake do not occur in the Galápagos Islands, and the only identified scorpaenid taken was Pontinus furcirhinus, which remained below $1 \%$ by number, and thus did not attain the importance of scorpaenids (rockfish) for California sea lions. However, most of 
Table 6. Greatest lengths $(\mathrm{mm})$ of well-preserved otoliths from fur seal and sea lion scats.

\begin{tabular}{|c|c|c|c|c|c|}
\hline & 1983 & 1984 & 1985 & 1986 & All years \\
\hline \multicolumn{6}{|c|}{ Fur seals } \\
\hline \multicolumn{6}{|c|}{ Myctophidae (OT 10) } \\
\hline Mean & 3.80 & 3.04 & 3.31 & 4.00 & 3.66 \\
\hline $\mathrm{SD}$ & 0.45 & 0.60 & 0.70 & 0.67 & 0.66 \\
\hline$n$ & 207 & 70 & 54 & 92 & 423 \\
\hline \multicolumn{6}{|c|}{ Bathylagidae (OT 16) } \\
\hline Mean & 2.81 & 2.75 & 2.83 & 2.26 & 2.69 \\
\hline $\mathrm{SD}$ & 0.18 & 0.41 & 0.36 & 0.32 & 0.41 \\
\hline$n$ & 24 & 101 & 45 & 33 & 203 \\
\hline \multicolumn{6}{|c|}{$\begin{array}{l}\text { Sardinops sagax } \\
\quad \text { (sardine) (OT 1) }\end{array}$} \\
\hline Mean & 3.29 & & & & \\
\hline SD & 0.20 & & & & \\
\hline$n$ & 43 & & & & \\
\hline \multicolumn{6}{|c|}{ Sea lions } \\
\hline \multicolumn{6}{|c|}{ Sardinops sagax (OT 1) } \\
\hline Mean & 3.30 & 2.85 & 3.08 & 3.09 & 3.06 \\
\hline SD & 0.21 & 0.28 & 0.37 & 0.37 & 0.35 \\
\hline$n$ & 66 & 102 & 83 & 83 & 334 \\
\hline \multicolumn{6}{|c|}{$\begin{array}{l}\text { Chlorophthalmus } \\
\quad \text { agassizii? (OT 8) }\end{array}$} \\
\hline Mean & 3.23 & 4.05 & 4.22 & 3.93 & 3.80 \\
\hline $\mathrm{SD}$ & 0.35 & 0.17 & 0.23 & 0.35 & 0.47 \\
\hline$n$ & 56 & 54 & 28 & 55 & 193 \\
\hline
\end{tabular}

Note: Only otolith types (OTs) contributing $>2 \%$ of all otoliths are included (see Table 1).

Table 5. Niche overlap in diet choice within species among sampling periods and between species, measured by means of Colwell and Futuyma's niche-overlap index (see Methods).

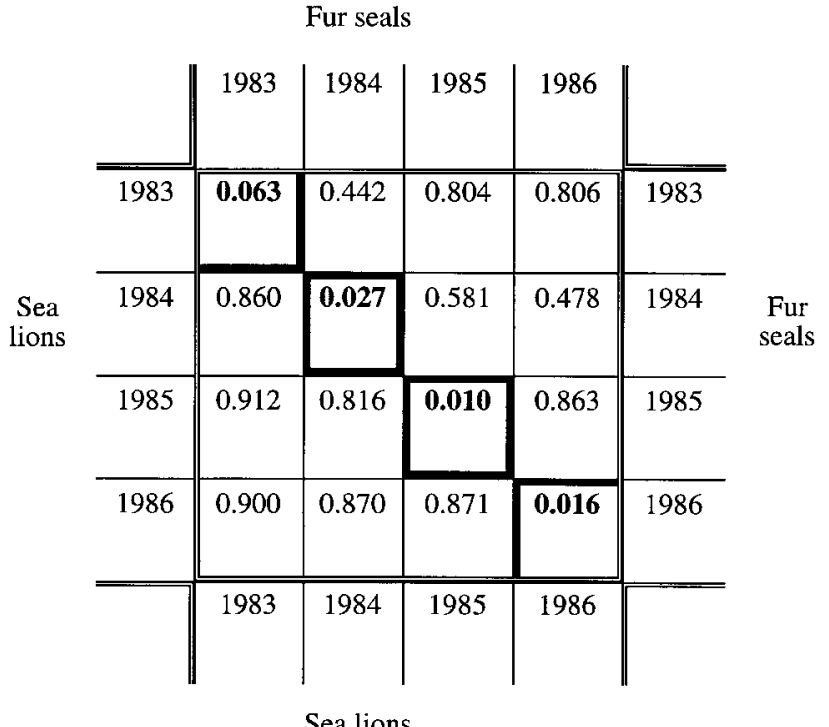

Note: Values above the diagonal (boldface type) show the comparison among years for fur seals and those below the diagonal show the same comparison for sea lions. The diagonal shows the overlap between fur seals and sea lions for each year.

the data on California sea lions cited above come from animals north of the breeding grounds and may therefore not be representative of diet choices of breeding females.

Large numbers of vomits were found only in 1983. This effect did not affect the comparison made in the later years of our study. However, it is clear from previous observations (Clarke and Trillmich 1980) that fur seals tend to regurgitate squid beaks, thus biasing the estimation of diet composition from scats. For this reason, and because squid were not identified to species, they were not included in our comparison. Squid beaks were never found in sea lion scats. Therefore, leaving out the squid component of the diet makes our assessment of the niche separation of the two species overconservative.

\section{Niche separation}

We found no significant dietary overlap between the two sympatric pinniped species, although both preyed upon a similar number of species (26 species for the fur seal and 24 for the sea lion). Also, we never found squid remains in sea lion samples but regularly found them in fur seal scats. For both species, the number of dominant prey species was rather small. Thus, both seem to specialize on prey species with a particular habit (nocturnal versus diurnal) and size. In fur seals three species (OT 10, OT 16, OT 1), and in sea lions two other species (OT 1, OT 8), contributed over $90 \%$ of otoliths. The abundance of species among the prey followed a logarithmic series, which characterizes situations with small numbers of abundant and large numbers of rare prey species (Magurran 1988).

\section{Annual variability in diets: El Niño 1983}

Our data cover 4 years, starting just after the strong environmental alterations caused by the ENSO phenomenon in 1982-1983. The first signs of starvation were seen in Galápagos sea lions and fur seals in March 1983 (Limberger 1985). Sampling for the present study began in September 
Fig. 3. Changes in percent dominance of prey in the sea lion diet over the 4 years of study. Note that the changes in percent dominance of OT 1 (sardine) are the opposite of changes in dominance of other prey items.

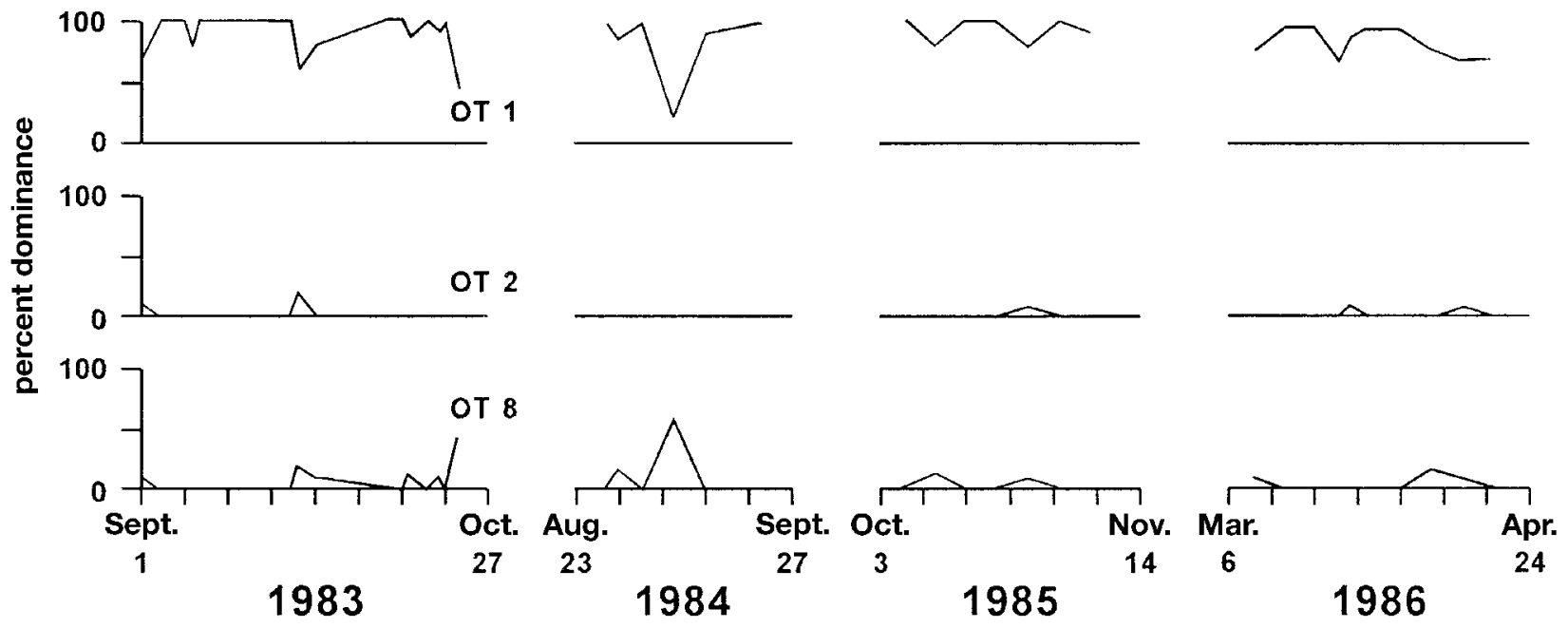

1983, when meteorological conditions had returned to normal but fish stocks were still reduced. However, it was in 1984 that the diets of both species differed most from the other sampling periods. The main prey types, myctophids and sardines, showed the smallest average otolith lengths in 1984 (Table 6), when these prey types were taken least. Fur seals then preyed much more on bathylagids, whose otolith lengths were nearly normal in 1984. A similar pattern was evident in sea lions, which fed on Chlorophthalmus sp. in 1984; the average size of this prey was greatest during that year and in 1985 (Table 6). Fish stocks were apparently still disturbed and recruitment may have failed, most likely because of oceanic changes related to the ENSO phenomenon.

Changing the diet according to prey availability has been called "switch feeding" for species pairs or "opportunistic feeding" in cases where more prey species and (or) different areas are involved (Kajimura 1984). California sea lions, for example, fed on Pacific hake during the summer and rockfish during the winter, when hake were not available (Antonelis et al. 1984). This kind of opportunism seems to be a general feature of otariids, since Gales and Pemberton (1994) reported that the Australian fur seal switched from fish to cephalopods during the summer, and Green et al. (1991) reported that Antarctic fur seals changed prey within a short period between two species of the myctophid genus Electrona. This last study showed even greater dietary changes between two collection periods 3 years apart. At San Nicolas Island in California, Lowry et al. (1991) showed that sea lions did not eat jack mackerel during the 1982-1983 ENSO phenomenon, since this species had abandoned the area. Sea lions fed mostly on northern anchovy when shoals were near the breeding grounds, and diet breadth increased when they were not (Lowry et al. 1991). In our study we did not find such an increase in diet breadth in 1984 (Table 2).

No information is available on prey abundance and distribution around the Galápagos Islands. We can assume, however, that sardine stocks off the Galápagos Islands changed in response to ENSO in a similar way to their Peruvian counterparts, migrating to deeper waters, or away from the Galápagos Islands (Arntz and Trillmich 1991). Other species might react similarly. Since the productive patch around the
Fig. 4. Percent frequency of various otolith types in the diets of fur seals and sea lions (relative to the total number of otoliths in all study years). There is almost no overlap in diet choice.

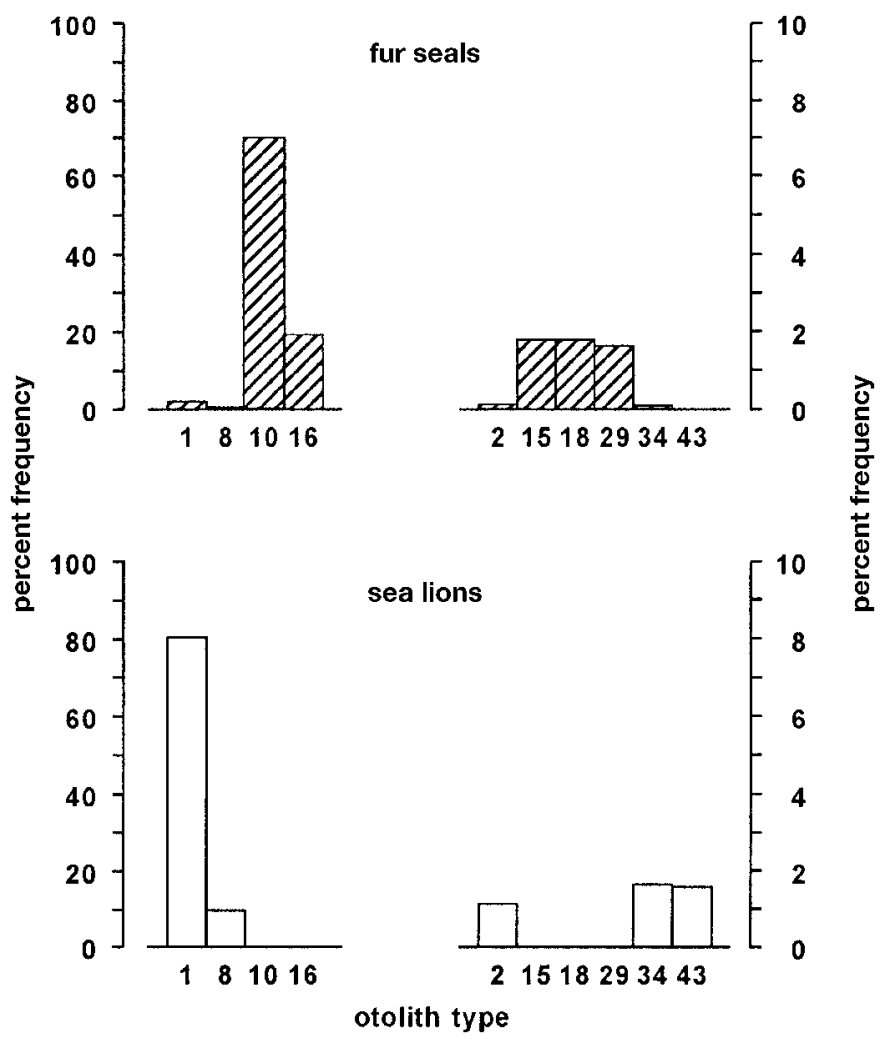

Galapagos archipelago is small, such a change would leave the pinniped species there with few alternative prey.

Antonelis and Fiscus (1980) suggested that the greatest overlap in pinniped foraging areas might occur during periods of highest prey abundance, while the greatest degree of segregation would occur when prey were least abundant. This seems unlikely in the case of Galápagos pinnipeds. Rather, if dietary overlap implies area overlap, the opposite was true for Galápagos pinnipeds. Only in 1983, shortly 
after El Niño, did fur seals eat some sardines, thus slightly increasing their niche overlap with sea lions (see Table 5).

\section{Resource partitioning}

At Cabo Hammond on Fernandina Island, both pinniped species use colonies at almost the same location, forage about the same distance from shore, and spend similar amounts of time at sea per foraging trip (Kooyman and Trillmich 1986a, 1986b). Wherever these animals swim from these colonies, they must forage over deep water, since Fernandina is a volcanic island rising steeply out of the ocean from $>2000 \mathrm{~m}$ depth. Detailed information on foraging areas is scant. Fur seals sometimes spend the day at sea resting 5-52 km offshore (Kooyman and Trillmich 1986a; Horning and Trillmich 1997; H. Whitehead and D. Day, personal communication) and sea lions feed at least $7-11 \mathrm{~km}$ offshore (Kooyman and Trillmich 1986b; Ponganis et al. 1990).

Given this overlap in habitat use, why do fur seals not feed on sardines and sea lions almost never on myctophids? Body size may be one explanatory factor. Adult female fur seals weigh, on average, around 27-28 kg (Trillmich 1987; Horning and Trillmich 1997) and are thus the smallest pinnipeds, whereas female Galápagos sea lions weigh about $100 \mathrm{~kg}$ (Ponganis et al. 1990). However, this fact alone cannot explain the differences found, and we can presently offer no strong hypothesis to explain the nearly absolute foodniche separation.

Sympatry occurs also between other pinnipeds. The best studied area is the California Current, where six pinniped species coexist. Otariids there preyed on shoaling fish and squid (Antonelis and Fiscus 1980). Within this area, California sea lions co-occur with northern fur seals off central California. In this case, the otariids used different foraging areas but hunted the same prey (Antonelis et al. 1990). Sea lions foraged closer to shore, while fur seals hunted over the continental slope in oceanic waters. Another example is the three sympatric Arctocephalus species at Macquarie Island, which again fed on similar prey but in different proportions (Green et al. 1990). Nothing has been published concerning their foraging areas. At Pudget Sound, Washington, California sea lions and harbor seals also overlap to some extent in their diets (Everitt et al. 1981). However, for pinnipeds that forage over the continental shelf, it provides an extensive foraging area where competition may be diluted. Pinnipeds that forage over the continental shelf also have the option of emigrating to better areas.

In oceanic island locations, such as the Galápagos archipelago, where emigration is nearly impossible, competition might be more intense, which could induce character displacement in sympatry. This might be the case in the Galápagos archipelago, where fur seals feed exclusively at night and sea lions almost exclusively during the day. Sea lions feed on densely schooling, fast-swimming larger prey, while fur seals feed on loosely schooling, slowly swimming smaller prey. Other fur seal species elsewhere depend less on the deep scattering layer than the Galápagos species, although the other species are also mainly nocturnal divers.

\section{Potential impact on fisheries}

Our data clearly imply that pelagic fishes off the Galápagos archipelago play a vitally important role as food for pinnipeds. The sardine is a commercially important fish species, and rising interest in the exploitation of myctophids for purposes of fish-meal production might be expected. There is as yet no fishing activity for small fish around the Galápagos archipelago, but because of its relative closeness to shore, pinniped foraging areas would likely overlap those of potential fisheries, making pinniped-fishery interactions unavoidable. Commercial fisheries would immediately threaten the pinnipeds' resources, so it is very important that the marine resources around the Galápagos archipelago remain protected.

\section{Acknowledgements}

Identification of some otoliths was kindly performed for us by J. Groves, R.J. Lavenberg, and G.A. Antonelis and by Mark Lowry and S. Hawes of the Southwest Fisheries Center, San Diego, Calif., U.S.A.; otolith 8 was identified by T. Hecht. Photographs and positions of fur seals foraging at sea during daytime were kindly provided by $\mathrm{H}$. Whitehead, who observed them on several occasions, as did D. Day. We greatly appreciate constructive criticism by G.A. Antonelis and an anonymous reviewer, which greatly improved the manuscript. E. Geißler kindly drew the graphs. We thank W. Wickler and the Max-Planck Institut für Verhaltensphysiologie, Seewiesen, for supporting us during this study. Writing was supported by a stipend from the Junta Nacional de Investigação (Portugal) / Deutscher Akademischer Austauschdienst (Germany) to T.D.

\section{References}

Ainley, D.C., Huber, H.R., and Bailey, K.M. 1982. Population fluctuations of California sea lions and the Pacific whiting fishery off Central California. Fish. Bull. 80: 253-258.

Antonelis, G.A., Jr., and Fiscus, C.H. 1980. The pinnipeds of the California Current. Calif. Coop. Oceanic Fish. Invest. Rep. 21: $68-78$.

Antonelis, G.A., Jr., Fiscus, C.H., and DeLong, R.L. 1984. Spring and summer prey of California sea lions, Zalophus californianus, at San Miguel Island, California, 1978-79. Fish. Bull. 82: 67-76.

Antonelis, G.A., Jr., Stewart, B.S., and Perryman, W.F. 1990. Foraging characteristics of female northern fur seals (Callorhinus ursinus) and California sea lions (Zalophus californianus). Can. J. Zool. 68: 150-158.

Arntz, W.E., and Trillmich, F. 1991. Biological consequences of the 1982-83 El Niño in the eastern Pacific. In The ecological effects of El Niño on otariids and phocids: responses of marine mammals to environmental stress. Edited by F. Trillmich and K.A. Ono. Springer-Verlag, Berlin. pp. 22-42.

Aurioles, D., Fox, C., Sinsel, F., and Tanos, G. 1984. Prey of the California sea lion (Zalophus californianus) in the Bay of La Paz, Baja California Sur, Mexico. J. Mammal. 65: 519-521.

Auster, P.J., Griswold, C.A., Youngbluth, M.J., and Bailey, T.G. 1992. Aggregations of myctophid fishes with other pelagic fauna. Environ. Biol. Fishes, 35: 133-139.

Bailey, K.M., and Ainley, D.G. 1982. The dynamics of California sea lion predation on Pacific hake. Fish. Res. (Amst.), 1: 163-176.

Beddington, J.R., Beverton, R.J.H., and Lavigne, D.M. 1985. Problems in estimating food consumption. In Marine mammals and fisheries. Edited by J.R. Beddington, R.J.H. Beverton, and D.M. Lavigne. George Allen and Unwin, London. pp. 272-275. 
Bowen, W.D., and Harrison, G.D. 1996. Comparison of harbour seal diets in two inshore habitats of Atlantic Canada. Can. J. Zool. 74: 125-135.

Cailliet, G.M., and Ebeling, A.W. 1990. The vertical distribution and feeding habits of two common midwater fishes (Leuroglossus stilbius and Stenobrachius leucopsarus) off Santa Barbara. Calif. Coop. Oceanic Fish. Invest. Rep. 31: 106-123.

Cherel, Y., and Ridoux, V. 1992. Prey species and nutritive value of food fed during summer to king penguin Aptenodytes patagonica chicks at Possession Island, Crozet archipelago. Ibis, 134: $118-127$.

Clarke, M.R., and Trillmich, F. 1980. Cephalopods in the diets of fur seals of the Galápagos Islands. J. Zool. (Lond.), 190: 211-215.

Clarke, T.A. 1973. Some aspects of the ecology of lanternfishes (Myctophidae) in the Pacific Ocean near Hawaii. Fish. Bull. 71: 401-433.

Colwell, R.K., and Futuyma, D.J. 1971. On the measurement of niche breadth and overlap. Ecology, 52: 567-576.

Croxall, J.P., Everson, I., Kooyman, G.L., Ricketts, C., and Davis, R.W. 1985. Fur seal diving behavior in relation to vertical distribution of krill. J. Anim. Ecol. 54: 1-8.

Daneri, G.A., and Coria, N.R. 1992. The diet of antarctic fur seals, Arctocephalus gazella, during the summer-autumn period at Mossman Peninsula, Laurie Island (South Orkneys). Polar Biol. 11: $565-566$.

Daneri, G.A., and Coria, N.R. 1993. Fish prey of Antarctic fur seals, Arctocephalus gazella, during the summer-autumn period at Laurie Island, South Orkney Islands. Polar Biol. 13: 287-289.

da Silva, J., and Neilson, J.D. 1985. Limitations of using otoliths recovered in scats to estimate prey consumption in seals. Can. J. Fish. Aquat. Sci. 42: 1439-1442.

Dellinger, T., and Trillmich, F. 1988. Estimating diet composition from scat analysis in otariid seals (Otariidae). Can. J. Zool. 66: $1865-1870$.

Doidge, D.W., and Croxall, J.P. 1985. Diet and energy budget of the Antarctic fur seal, Arctocephalus gazella, at South Georgia. In Antarctic nutrient cycles and food webs. Edited by W.R. Siegfried, P.R. Condy, and R.M. Laws. Springer-Verlag, Berlin. pp. 543-550.

Everitt, R.D., Gearin, P.J., Skidmore, J.S., and DeLong, R.L. 1981. Prey items of harbor seals and California sea lions in Puget Sound, Washington. Murrelet, 62: 83-86.

Fahrbach, E., Trillmich, F., and Arntz, W. 1991. The time sequence and magnitude of physical effects of El Niño in the eastern Pacific. In The ecological effects of El Niño on otariids and phocids: responses of marine mammals to environmental stress. Edited by F. Trillmich and K.A. Ono. Springer-Verlag, Berlin. pp. 8-21.

Feldkamp, S.D., DeLong, R.L., and Antonelis, G.A., Jr. 1989. Diving patterns of California sea lions, Zalophus californianus. Can. J. Zool. 67: 872-883.

Francis, J., Boness, D.J., and Ochoa-Acuña, H. 1998. A protracted foraging and attendance cycle in female Juan Fernandez fur seals. Mar. Mammal Sci. 14: 552-574.

Gales, R., and Pemberton, D. 1994. Diet of the Australian fur seal in Tasmania. Aust. J. Mar. Freshwater Res. 45: 653-664.

Gartner, J.V., Jr. 1991. Life histories of three species of lanternfishes (Pisces: Myctophidae) from the eastern Gulf of Mexico. 1. Morphological and microstructural analysis of sagittal otoliths. Mar. Biol. (Berl.), 111: 11-20.

Gartner, J.V., Jr. 1993. Patterns of reproduction in the dominant lanternfish species (Pisces: Myctophidae) of the eastern Gulf of Mexico, with a review of reproduction among tropical-subtropical Myctophidae. Bull. Mar. Sci. 52: 721-750.
Gentry, R.L. 1998. Behavior and ecology of the northern fur seal. Princeton University Press, Princeton, N.J.

Gentry, R.L., Costa, D.P., Croxall, J.P., David, J.H.M., Davis, R.W., Kooyman, G.L., Majluf, P., McCann, T.S., and Trillmich, F. 1986. Synthesis and conclusions. In Fur seals: maternal strategies on land and at sea. Edited by R.L. Gentry and G.L. Kooyman. Princeton University Press, Princeton, N.J. pp. 220-264.

Glynn, P.W. 1988. El-Niño - Southern Oscillation 1982-1983: nearshore population, community, and ecosystem responses. Annu. Rev. Ecol. Syst. 19: 309-345.

Green, K., Burton, H.R., and Williams, R. 1989. The diet of antarctic fur seals Arctocephalus gazella (Peters) during the breeding season at Heard Island. Antarct. Sci. 1: 317-324.

Green, K., Williams, R., Handasyde, K.A., Burton, H.R., and Shaughnessy, P.D. 1990. Interspecific and intraspecific differences in the diets of fur seals, Arctocephalus species (Pinnipedia: Otariidae), at Macquarie Island. Aust. Mammal, 13: 193-200.

Green, K., Williams, R., and Burton, H.R. 1991. The diet of antarctic fur seals during the late autumn and early winter around Heard Island. Antarct. Sci. 3: 359-361.

Harcourt, R.G., Schulman, A.M., Davis, L.S., and Trillmich, F.T. 1994. Summer foraging by lactating female New Zealand fur seals (Arctocephalus forsteri) off Otago Peninsula, New Zealand. Can. J. Zool. 73: 678-690.

Härkönen, T. 1986. Guide to the otoliths of the bony fishes of the northeast Atlantic. Danbiu ApS, Hellerup, Denmark.

Hecht, T. 1978. A descriptive systematic study of the otoliths of the neopterygean marine fishes of South Africa. Part I. Introduction. Trans. R. Soc. S. Afr. 43: 191-197.

Hobson, E.S. 1966. Visual orientation and feeding in seals and sea lions. Nature (Lond.), 210: 326-327.

Hopkins, T.L., and Gartner, J.V., Jr. 1992. Resource partitioning and predation impact of a low latitude myctophid community. Mar. Biol. (Berl.), 114: 185-197.

Horning, M., and Trillmich, F. 1997. Ontogeny of diving behaviour in the Galápagos fur seal. Behaviour, 134: 1211-1257.

Huber, H.R., Ainley, D.G., Morrell, S., LeValley, R.R., and Strong, C.S. 1979. Studies of marine mammals at the Farallon Islands, California, 1977-78. Marine Mammal Commission, NTIS no. PB80-111602. U.S. Department of Commerce, Springfield, Va.

Jobling, M., and Breiby, A. 1986. The use and abuse of fish otoliths in studies of fish feeding habits of marine piscivores. Sarsia, 71: 265-274.

Kajimura, H. 1984. Opportunistic feeding of the northern fur seal, Callorhinus ursinus, in the eastern North Pacific Ocean and eastern Bering Sea. NOAA Tech. Rep. NMFS SSRF-779.

Kear, J.K. 1992. The diet of Antarctic squid: comparison of conventional and serological gut content analyses. J. Exp. Mar. Biol. Ecol. 156: 161-178.

Kooyman, G. L., and Trillmich, F. 1986a. Diving behavior of Galápagos fur seals. In Fur seals: maternal strategies on land and at sea. Edited by R.L. Gentry and G.L. Kooyman. Princeton University Press, Princeton N.J. pp. 186-195.

Kooyman, G.L., and Trillmich, F. 1986b. Diving behavior of Galápagos sea lions. In Fur seals: maternal strategies on land and at sea. Edited by R.L. Gentry and G.L. Kooyman. Princeton University Press, Princeton N.J. pp. 209-219.

Limberger, D. 1985. El Niño on Fernandina. In El Niño en las islas Galápagos : el evento de 1982-1983. Edited by G. Robinson and E.M. del Pino. Fundación Charles Darwin para las Islas Galápagos, Quito, Ecuador. pp. 211-225.

Linkowsky, T.B. 1991. Otolith microstructure and growth patterns during the early life history of lanternfishes (family Myctophidae). Can. J. Zool. 69: 1777-1792. 
Lowry, M.S., Stewart, B.S., Heath, C.B., Yochem, P.K., and Francis, J.M. 1991. Seasonal and annual variability in the diet of California sea lions Zalophus californianus at San Nicolas Island, California, 1981-86. Fish. Bull. 89: 331-336.

Lucas, F.A. 1899. The food of northern fur seals. In The fur seals and fur-seal islands of the North Pacific Ocean. Part 3. Edited by D.S. Jordan Government Printing Office, Washington, D.C. pp. 59-68.

Magurran, A.E. 1988. Ecological diversity and its measurement. Croom Helm, London.

Majluf, P. 1991. EL Niño effects on pinnipeds in Peru. In The ecological effects of El Niño on otariids and phocids: responses of marine mammals to environmental stress. Edited by F. Trillmich and K.A. Ono. Springer-Verlag, Berlin. pp. 55-65.

Maynard, S.D., Riggs, F.V., and Walters, J.F. 1975. Mesopelagic micronekton in Hawaiian waters: faunal composition,standing stock, and diel vertical migration. Fish. Bull. 73: 726-736.

Miya, M. 1994. Seasonal occurrence of deep-sea bathylagid fishes in Sagami Bay, central Japan, with notes on their reproduction. Jpn. J. Ichthyol. 40: 433-440.

Murie, D.J., and Lavigne, D.M. 1985. A technique for the recovery of otoliths from stomach contents of piscivorous pinnipeds. J. Wildl. Manage. 49: 910-912.

North, A.W., Croxall, J.P., and Doidge, D.W. 1983. Fish prey of the Antarctic fur seal Arctocephalus gazella at South Georgia. Br. Antarct. Surv. Bull. 61: 27-37.

Paxton, J.R. 1967. A distributional analysis for the lanternfishes (family Myctophidae) of the San Pedro Basin, California. Copeia, 2: 422-440.

Perez, M.A., and Bigg, M.A. 1986. Diet of northern fur seals, Callorhinus ursinus, off western North America. Fish. Bull. 84: 957-971.

Pierce, G.J., Boyle, P.R., Watt, J., and Grisley, M. 1993. Recent advances in diet analysis of marine mammals. Symp. Zool. Soc. Lond. No. 66. pp. 241-261.

Ponganis, P.J., Ponganis, E.P., Ponganis, K.V., Kooyman, G.L., Gentry, R.L., and Trillmich, F. 1990. Swimming velocities in otariids. Can. J. Zool. 68: 2105-2112.

Reid, K. 1995. The diet of Antarctic fur seals (Arctocephalus gazella Peters 1875) during winter at South Georgia. Antarct. Sci. 7: 241-249.

Reid, K., and Arnould, J.P.Y. 1996. The diet of Antarctic fur seals Arctocephalus gazella during the breeding season at South Georgia. Polar Biol. 16: 105-114.

Rodhouse, P.G., White, M.G., and Jones, M.R.R. 1992. Trophic relations of the cephalopod Martialia hyadesi (Teuthoidea: Ommastrephidae) at the Antarctic Polar Front, Scotia Sea. Mar. Biol. (Berl.), 114: 415-421.

SPSS Inc. 1997. SPSS for Windows-statistical package for the social sciences, standard version. Release 8.0 (Dez. 22). SPSS Inc., Chicago.

Trillmich, F. 1987. Galápagos fur seal, Arctocephalus galapagoensis. NOAA Tech. Rep. NMFS 51. pp. 23-27.

Trillmich, F. 1990. The behavioral ecology of maternal effort in fur seals and sea lions. Behaviour, 114: 3-20.

Trillmich, F., and Dellinger, T. 1991. The effects of El Niño on Galápagos pinnipeds. In The ecological effects of El Niño on otariids and phocids: responses of marine mammals to environmental stress. Edited by F. Trillmich and K.A. Ono. SpringerVerlag, Berlin. pp. 66-74.

Trillmich, F., and Limberger, D. 1985. Drastic effects of El Niño on Galápagos pinnipeds. Oecologia (Berl.), 67: 19-22.

Trillmich, F., and Mohren, W. 1981. Effects of the lunar cycle on the Galápagos fur seal, Arctocephalus galapagoensis. Oecologia (Berl.), 48: 85-92.

Trillmich, F., and Ono, K.A. 1991. Pinnipeds and El Niño: responses to environmental stress. Springer-Verlag, Berlin.

Vaz-Ferreira, R. 1982. Mammals in the seas. Arctocephalus australis Zimmermann, South American fur seal. FAO Fish. Ser. 5: 497-508.

Vaz-Ferreira, R., and Ponce de Leon, A. 1987. South American fur seal, Arctocephalus australis, in Uruguay. NOAA Tech. Rep. NMFS 51: 29-32.

Villavicencio de Muck, Z., and Muck, P. 1983. La ración de mantenimiento, la densidad de mantenimiento y la efficiencia de crecimiento de Engraulis ringens y Sardinops sagax como una medida de su potencia ecologica. Bol. Inst. Mar. Peru, 7: 69-108.

Zar, J.H. 1984. Biostatistical analysis. 2nd ed. Prentice-Hall, Englewood Cliffs, N.J. 